\title{
Environmental Education Resources from Federal and State Agencies ${ }^{1}$
}

\author{
Martha C. Monroe and Alison W. Bowers²
}

Going on a field trip? Want a spiffy new poster? Looking for a guest speaker? Or do you just need to know more about wildland fire, endangered species, coastal management, or invasive exotics? Many agencies are available to provide information, share resources, support field trips, and contribute to your environmental education (EE) programming and other needs relating to natural resources. This fact sheet explores federal and state agencies in Florida with major educational resources. It offers an introduction to these agencies so you can find the resources you need.

\section{Federal Natural Resource Agencies}

Several agencies of the federal government own and manage land in Florida and offer programs at the areas they manage. A few other federal agencies do not own land but offer programs and resources through their local offices or state agency affiliate. (See Table 1 for a summary of these federal contacts.) Each agency operates under separate legislative mandates, so you can expect to find different management goals, programs, and resources at each one. The federal government hosts a website (http://www.free. ed.gov) that lists hundreds of educational resources from over 45 federal agencies.

The recent interest in encouraging youth and families to spend time outdoors has created a number of special programs at both the federal and state levels. Hands on the Land (http://www.handsontheland.org), is a cooperative program of federal agencies to engage school groups with public lands through outdoor classrooms. Get Outdoors Florida! (http://getoutdoorsflorida.com/) is a coalition of partners that address natural resource conservation, health, and public well-being. Other initiatives are linked through the Children and Nature Network (http://www.cnaturenet. org), an outcome of Richard Louv's book Last Child in the Woods.

\section{US Forest Service (FS)}

The US Forest Service, part of the United States Department of Agriculture, manages 193 million acres of national forests and grasslands, assists landowners through state and private forestry programs, and conducts natural resources research. National forests are managed for multiple use in order to protect biodiversity, as well as to provide water, wood, recreation opportunities, and other services to meet our needs. Forest Service employees help people use and enjoy the forest while conserving natural resources. Here in Florida, three national forests are managed through the National Forests of Florida office in Tallahassee (http:// www.fs.usda.gov/florida). The three forests provide excellent recreation opportunities including hiking, swimming, motorized trails, and camping opportunities. They also help manage the Florida Trail, a 1,400 mile hiking trail across our state (http://www.fs.usda.gov/fnst).

1. This document is FOR 100, one of a series of the School of Forest Resources and Conservation, Florida Cooperative Extension Service, Institute of Food and Agricultural Sciences, University of Florida. First published September 2001. Minor Revision January 2007. Major revision December 2012. Please visit the EDIS website at htttp://edis.ifas.ufl.edu.

2. Martha C. Monroe, professor; and Alison W. Bowers, Extension assistant; School of Forest Resources and Conservation, Institute of Food and Agricultural Sciences, University of Florida, Gainesville, FL 32611-0410. 
Forest Service personnel often provide educational talks to school groups and other organizations and the Learning Center link on their website provides access to information for parents, teachers, and youth (http://www.fs.usda.gov/ main/florida/learning). The national site has an exciting website for youth: http://www.discovertheforest.org. For more information on the USDA Forest Service, National Forests in Florida please contact one of their offices.

National Forests of Florida, Tallahassee Office -- 850-5238500. http://www.fs.usda.gov/florida

Ocala National Forest in north central Florida includes crystal-clear springs, off-road trail systems, three visitor centers, and the location of Marjorie Kinnan Rawlings' story The Yearling.

Apalachicola National Forest is south of Tallahassee and is the largest national forest in Florida. It includes habitat for the endangered red-cockaded woodpecker, recreation sites, and the watersheds for six different rivers.

Osceola National Forest straddles I-10 between Lake City and Jacksonville and helps maintain a biological corridor to the Okeefenokee Swamp to the north. It interprets cultural history as well as natural history with the Battle of Olustee, fought during the Civil War.

\section{Natural Resources Conservation Service (NRCS)}

The Natural Resources Conservation Service, part of the U.S. Department of Agriculture, helps private landowners protect the natural resources on their land. It emphasizes science-based assistance and partnerships at the community level (http://www.nrcs.usda.gov). The NRCS mission is to provide leadership in a partnership effort to help people conserve, improve, and sustain natural resources, primarily at the local level with each county's soil and water conservation district. The Florida branch of the NRCS is located in Gainesville (http://www.fl.nrcs.usda.gov/).

The NRCS provides publications and curriculum guides on soil, soil conservation, backyard conservation, conservation history, land stewardship, and natural resource management on their Teachers and Students link from their home page, (http://www.nrcs.usda.gov/wps/portal/nrcs/asr/ national/students/?atype $=$ Teachers and Students). These materials can be ordered or downloaded from the Web (Table 1). The Gainesville office can provide posters, fact sheets, and brochures. NRCS Branch Office -- Gainesville, 352-338-9500

\section{National Park Service (NPS)}

The National Park Service, a branch of the U.S. Department of the Interior, manages 390 national parks, monuments, recreation areas, battlefields, historic structures, parkways, and wild and scenic rivers (http://www.nps.gov). The NPS preserves the valuable natural and cultural resources for the enjoyment, education, and inspiration of this and future generations. Parks are managed for visitors but are not used to harvest resources. Florida has one world famous national park, the Everglades, and many smaller parks, battlefields, and monuments that preserve important aspects of our history. Most parks offer interpretive and educational programs, camping sites, and hiking trails.

The federal website has links on their home page for teachers (http://www.nps.gov/learn/) and kids (http:// www.nps.gov/webrangers/). Many parks have curriculum resources specific to their location, which can be accessed from the Teacher/Curriculum link. Parks as Classrooms ${ }^{\oplus}$ is the curriculum-based education program that facilitates the connection between park education specialists and local educators. The resources available through this program vary from park to park but may include curriculum guides, videos, and workshops.

All twelve national park sites in Florida can be found on their index (http://www.nps.gov/state/fl/index. htm? program=parks), and each can be explored on its website:

Big Cypress National Preserve -- Ochopee, http://www. nps.gov/bicy/

Biscayne National Park - Homestead, http://www.nps.gov/ bisc/

Canaveral National Seashore -- Titusville, http://www.nps. gov/cana/

Castillo De San Marcos National Monument -- St. Augustine, http://www.nps.gov/casa/

De Soto National Memorial -- Bradenton, http://www.nps. gov/deso/

Dry Tortugas National Park -- Key West, http://www.nps. gov/drto/

Everglades National Park -- Homestead, http://www.nps. gov/ever/index.htm 
Fort Caroline National Memorial -- Jacksonville, http:// www.nps.gov/foca/

Fort Matanzas National Monument -- St. Augustine, http://www.nps.gov/foma/

Gulf Islands National Seashore -- Gulf Breeze, http://www. nps.gov/guis/

Gullah/Geechee Cultural Heritage Corridor - Jacksonville, http://www.nps.gov/guge/

Timucuan Ecological \& Historic Preserve -- Jacksonville, http://www.nps.gov/timu/

\section{Fish and Wildlife Service (FWS)}

The Fish and Wildlife Service, a branch of the U.S. Department of the Interior, works to conserve, protect, and enhance fish and wildlife and their habitats for the benefit of present and future generations (http://www.fws.gov/). There are almost 700 field units and installations across the country, including National Wildlife Refuges, fish hatcheries, ecological field offices, and law enforcement offices. The National Wildlife Refuge System consists of more than 93 million acres of land set aside for wildlife. Much of this land is in Alaska, although there are 28 refuges and one hatchery in Florida. Many refuges offer recreational and educational opportunities for visitors; a partial listing of Florida refuges appears below. Visit the FWS Web site for a complete directory http://www.fws.gov/southeast/refuges/refuges-by-state. html\#florida)

The FWS is responsible for protecting endangered species and can provide publications, maps, and videos on topics such as birds, fish, and wetlands. Let's Go Outside is the agency program that connects people with nature (http:// www.fws.gov/letsgooutside/). Many national wildlife refuges offer educational programs as well.

Crystal River National Wildlife Refuge -- Crystal River, http://www.fws.gov/crystalriver/

Archie Carr National Wildlife Refuge --Vero Beach, http://www.fws.gov/archiecarr/

St. Vincent National Wildlife Refuge -- Apalachicola, http://www.fws.gov/saintvincent/

St. Marks National Wildlife Refuge -- St. Marks, http:// www.fws.gov/saintmarks/
Chassahowitzka National Wildlife Refuge -- Crystal

River, http://www.fws.gov/chassahowitzka/

Lower Suwannee National Wildlife Refuge -- Chiefland, http://www.fws.gov/lowersuwannee/

J. N. Ding Darling National Wildlife Refuge --Sanibel, 239-472-1100 http://www.fws.gov/dingdarling/

Florida Panther National Wildlife Refuge -- Naples, http://www.fws.gov/floridapanther/

Lake Woodruff National Wildlife Refuge -- De Leon Springs, http://www.fws.gov/lakewoodruff/

Arthur R. Marshall Loxahatchee National Wildlife Refuge, Boynton Beach, http://www.fws.gov/loxahatchee/

Hobe Sound National Wildlife Refuge -- Hobe Sound, http://www.fws.gov/hobesound/

Merritt Island National Wildlife Refuge --Titusville, http://www.fws.gov/merrittisland/

National Key Deer Refuge -- Big Pine Key, http://www.fws. gov/nationalkeydeer/

Pelican Island National Wildlife Refuge -- Vero Beach, http://www.fws.gov/pelicanisland/

\section{Environmental Protection Agency (EPA)}

The mission of the U.S. Environmental Protection Agency is to protect human health and safeguard the natural environment upon which life depends (http://www.epa. gov/). The EPA regulates and protects clean air, clean and safe water, waste management, restoration of contaminated sites, environmental risk management, and compliance with environmental law. Florida is part of Region 4, with headquarters in Atlanta, Georgia, but the Florida Department of Environmental Protection (DEP) is charged with carrying out many EPA programs to protect air and water quality and manage waste in Florida.

The EPA Office of Environmental Education offers a cornucopia of environmental education materials: curriculum and activity guides, technical reports, fact sheets, grants for environmental education projects, awards, community service project ideas, workshops, and conferences. The curriculum guides and other publications cover a vast array of topics including solid waste, non-point pollution, human health, endangered species, service learning, global warming, and energy conservation. The EPA sponsors the Adopt 
Your Watershed campaign to help individuals and organizations protect and restore rivers, wetlands, lakes, estuaries, and other water sources. A link to kids on the main page takes visitors to a site for students, educators, and parents with games, resources, and lesson plans. (http://www.epa. gov/students/index.html).

\section{United States Geological Survey (USGS)}

The U. S. Geological Survey, in the Department of Interior, conducts research and provides information on natural hazards, natural resources, and the environment. USGS facilitates solutions to national and global natural resource issues by supplying vast amounts of earth and biological data (http://www.usgs.gov). The USGS maintains a state office in Tallahassee and field offices in Altamonte Springs, Ft. Myers, Gainesville, Homestead, Jacksonville, Miami, Ocala, Ochopee, St. Petersburg Beach, Stuart, Tallahassee, Tampa, and West Palm Beach.

The USGS offers an outstanding collection of educational materials about biology, geology, mapping, and water (http://education.usgs.gov/). You can order or download teaching packets, posters, fact sheets, booklets, and CDROMs. USGS has created several fascinating 3-D paper models that illustrate the dynamic concepts of many natural resources including volcanoes, earthquakes, and coral reefs. Topographic maps for any region of the country can be downloaded from their website as well (http://www.usgs. gov/pubprod/). Real-time information about water, stream flows, floods, and earthquakes can be collected from the Florida portion of the website (http://www.usgs.gov/state/ state.asp? State $=\mathrm{FL}$ ).

\section{National Oceanic and Atmospheric Administration (NOAA)}

The National Oceanic and Atmospheric Administration is part of the Department of Commerce. NOAA's mission is to describe and predict environmental changes and to conserve and manage the coastal and marine resources in the United States (http://www.noaa.gov). There are five major agencies within NOAA: National Weather Service; National Ocean Service; Office of Oceanic and Atmospheric Research; National Environmental Satellite, Data, and Information Sources; and National Marine Fisheries Service. The National Weather Service has offices throughout the state and the National Marine Fisheries Service has offices and laboratories in St. Petersburg, Miami, and Panama City. NOAA supports the National Estuarine Research Reserve System, a network of 27 national reserves that protects over one million acres of estuaries. Florida is home to three
Estuarine Research Reserves, which are managed by Florida DEP through a cooperative agreement with NOAA.

NOAA provides a wealth of educational materials on weather, climate change, oceans, coastal areas, satellites, space, and careers (http://www.education.noaa.gov/). NOAA is a major supporter of the Global Learning and Observations to Benefit the Environment (GLOBE) Program, a worldwide, school-based education program where teachers and students measure and report environmental data. NOAA is also the lead agency in the Climate Literacy and Energy Awareness Network (http://cleanet.org). The three Estuarine Research Reserves in Florida have educational visitor centers and a variety of programs (http://www.nerrs. noaa.gov/).

Apalachicola Reserve -- Franklin County, http://www. nerrs.noaa.gov/Reserve.aspx?ResID=APA

Guana Tolomato Matanzas Reserve -- St. Johns and Flagler Counties, http://www.nerrs.noaa.gov/Reserve. aspx?ResID $=$ GTM

Rookery Bay Reserve -- Collier County, http://www.nerrs. noaa.gov/Reserve.aspx?ResID=RKB

\section{State Agencies}

Florida agencies have a long-term commitment to environmental education, though their funding for EE programs changes from year to year. In 1992, the State Committee for Environmental Education (SCENE) was established to facilitate the dispersal of the EE information and materials of all state agencies. The Get Outdoors Florida partnership (http://getoutdoorsflorida.com/) involves many state agencies that serve youth and families and encourage conservation activities.

\section{Department of Environmental Protection (DEP)}

The Florida Department of Environmental Protection protects air and water quality, ensures proper waste management, carries out EPA programs, manages the state park system, and oversees a land buying program (http://www. dep.state.fl.us/). DEP consists of six regulatory districts in Florida, with each office providing information, speakers, programs, and other services.

DEP's Office of Environmental Education (OEE) works to improve environmental literacy and citizenship among Florida residents and visitors (http://www.dep.state. fl.us/secretary/ed/). The OEE produces and maintains 
a collection of EE materials and is involved with public outreach and education for DEP. The award-winning LIFE (Learning in Florida's Environment) program (http:// www.dep.state.fl.us/secretary/ed/lifeprogram.htm) links classrooms with local parks and other natural areas across the state and offers engaging field science activities. The Division of Recreation and Parks is responsible for the management of Florida's award-winning system of 159 state parks, trails, and recreation areas. These parks provide a myriad of recreation and education opportunities for visitors such as swimming, hiking, canoeing, camping, snorkeling, bird watching, and bicycling. A park guide is available by contacting DEP. The Office of Greenways and Trails oversees 38 canoe trails with over 1,000 miles of waterway, over 200 miles of multi-use trails, and the 110 miles of the Marjorie Harris Carr Cross Florida Greenway in north central Florida.

\section{Department of Agriculture and Consumer Services (DACS)}

The Florida Department of Agriculture and Consumer Services works to protect consumers and support Florida agriculture (http://www.freshfromflorida.com/). This involves a wide range of responsibilities such as investigating business practices, inspecting scales and gas pumps, working with farmers, managing more than a million acres of state forest lands, and protecting homes from wildfires. They have a number of resources for teachers and students (http://www.freshfromflorida.com/teachers_students.html). The Department helps support Florida Ag in the Classroom, a non-profit organization that helps educate Florida youth about the role of agriculture and its relation to the environment, economy, health and quality of life for Florida citizens, as well as several resources on wildfire, Florida's forests, wildflowers, aquaculture, and honeybees.

The Florida Forest Service (FFS) a branch of DACS, works to protect and manage forest resources in Florida (http:// www.floridaforestservice.com/). FFS's main programs focus on state land management, wildfire, and forestry technical assistance through fifteen field offices. DOF manages 35 state forests that cover more than one million acres (http:// www.floridaforestservice.com/state_forests/index.html). Management of these forests combines public use and protection of biological diversity. Major education efforts include the Florida Teachers Forestry Tour, Bear Creek Educational Forest, Future Farmers of America (FFA) Forestry Contests and summer camp, and the Healthy Forest Education Kit (http://sfrc.ufl.edu/extension/ee/foresthealth. html). Contact information for your county forester can be found on their web site: http://www.floridaforestservice. com/field_operations/county_foresters/index.html. FFS is a strong supporter of Project Learning Tree (PLT) in Florida (http://sfrc.ufl.edu/plt). PLT is an interdisciplinary, national curriculum resource for grades Pre-K-12. PLT provides activities to teach young people about trees and forests while developing critical thinking skills, decision-making abilities, and a commitment to the environment. Activities have been correlated to the Next Generation Sunshine State Standards. Educators attend workshops held across the state to obtain the curriculum materials and receive training in the use of these materials. Online workshops are also available to help educators receive materials.

\section{Fish and Wildlife Conservation Commission (FWCC)}

The Florida Fish and Wildlife Conservation Commission manages Florida's fish and wildlife resources for their long-term welfare and the benefit of people. The major units focus on habitat, hunting and game management, freshwater fisheries, marine fisheries, law enforcement, economic contributions, community relations, licenses and permitting, public access and wildlife viewing, planning and policy, and research.

The Education program (http://myfwc.com/education/)is responsible for a variety of programs that target adults and families, youth and students, educators, outdoor skills, and learning about wildlife. Educators can attend workshops and receive quality materials about schoolyard wildlife, Florida Black Bears, and Project WILD, all of which are liked to the Sunshine State Standards and have been evaluated for quality. Junior Hunter Safety, Junior Birder, archery, and aquatics education are also sponsored by this agency. FWCC operates several youth camps and nature centers that offer programs and workshops on wildlife, fisheries, and hunting. The Everglades Youth Conservation Camp offers one-day, three-day, and week-long programs for schools and individuals.

Project WILD is a national, interdisciplinary conservation and environmental education program that teaches young people, in grades K-12, about wildlife. The activities in the curriculum guide can be used in formal and informal programs and have been correlated to the Sunshine State Standards. Workshops are held throughout the state for educators to learn about and receive Project WILD resources (http://myfwc.com/education/educators/project-wild/).

The agency also sponsors programs for youth directly, including fishing camps, coloring books, and clinics (http:// myfwc.com/education/youth/). 
Joe Budd Youth Conservation Center, west of Midway -- http://myfwc.com/education/outdoor-skills/joe-budd/

Beau Turner Youth Conservation Center, near Capps -- http://myfwc.com/education/outdoor-skills/beau-turner/

Chinsegut Nature Center, north of Brooksville -- http:// myfwc.com/education/outdoor-skills/chinsegut/

\section{Water Management Districts (WMD)}

The quality and quantity of Florida's wetlands and water resources are managed by five Water Management Districts. These districts are responsible for creating flood protection programs, developing water management plans, performing research, overseeing well construction, and acquiring and managing lands to protect water resources. The five districts are: Northwest Florida Water Management District, South Florida Water Management District, Southwest Florida Water Management District, St. Johns River Water Management District, and Suwannee River Water Management District.

Each WMD provides its own set of educational programs and materials and the extent and range of materials vary. One district may offer a speakers bureau, video library, and curriculum guides, while another district might offer grant opportunities and fact sheets on water conservation. All districts manage water conservation areas that are set aside to protect watersheds and are often open to the public. These areas can serve as field trip destinations and provide recreational opportunities such as hiking, camping, bicycling, and canoeing.

One educational program supported by the Southwest Florida Water Management District is Project WET (Water Education for Teachers). Project WET is an interdisciplinary, national curriculum promoting awareness and appreciation of water resources. The activities have been correlated to the Sunshine State Standards and can be used in classrooms and extracurricular programs. Educators interested in receiving the curriculum must attend a Project WET workshop and receive training in order to use the material. In order to obtain this training you must attend a Project WET workshop. Several program coordinators operate across Florida and can be located at the national web site: http://projectwet.org/where-we-are/location/ florida/.

The St. Johns River Water Management District supports an educational program called the Great Water Odyssey (http://floridaswater.com/education/). This program is designed for third, fourth, and fifth grade teachers to teach youth about water resources and their protection and conservation. The cartoon animation and web-based resource is free to educators. Students can be tested with practice questions modeled after the FCAT curriculum.

\section{Department of Education (DOE)}

The Florida Department of Education provides assistance and resources for the educational system throughout Florida. DOE sets state standards, certifies teachers, and provides for school safety. The DOE provides for a system of education that provides opportunity to students for knowledge and skills through learning opportunities. Many of the Sunshine State Standards in science address environmental topics. Searching with keywords can help identify appropriate standards through a search engine (http://tools. fcit.usf.edu/sss/) or the state database (http://www.cpalms. org/Standards/FLStandardSearch.aspx).

The Bureau of Curriculum and Instruction houses an environmental education database of resources for educators (http://www.fldoe.org/bii/Curriculum/ Environmental_Ed/).

\section{Department of Transportation (DOT)}

The Florida Department of Transportation is responsible for moving people and goods efficiently through Florida while also preserving the environment. DOT, divided into eight districts, oversees 41,000 miles of the state highway system and 6,000 bridges and is involved with transportation alternatives, public transportation, and safety programs.

DOT offers an Adopt-A-Highway program where organizations make a two-year commitment to pick up trash along a stretch of highway. In return, DOT provides safety information, safety vests, litter bags, and litter pickup. DOT's Environmental Management Office (EMO) administers the Scenic Highways Program and Highway Beautification Program. EMO offers a number of publications on wildflowers, archeology, cultural resources, scenic highways, and greenways. The DOT also offers a bicycling and pedestrian safety program. This programs aids in the education and facilitation of safe bike riding and pedestrian safety. It governs the Florida Crossing Guard Training Program, the Florida Traffic Safety Education Program, and the Safe Routes to School Program.

The Florida DOT provides management of highways, scenic highways, seaports, pedestrian and bicycling paths, airports and the Florida Rail Commission. The Florida DOT maintains and dictates the policies and management 
of these public attributes to ensure safety and reliability. The Florida DOT is also a partner with MyFloridaBeautiful. com. This program provides for the Florida's highway Beautification Program that provides information to landscape architects, community leaders, and landscape contractors. This provides for the natural and scenic beauty of the Florida highway system.

\section{Florida Institute for Phosphate Research (FIPR)}

The Florida Institute for Phosphate Research conducts and funds research that focuses on the phosphate mining and fertilizer industry in Florida. Phosphate is an essential nutrient for life and is mined in several regions of Florida. The FIPR provides resources, field trips and public information about the importance of phosphate and its management in Florida.

FIPR provides information and a K-12 curriculum that addresses phosphate-related issues while building skills in math, science, social studies, and language arts. The lessons in this curriculum have been correlated to the Sunshine State Standards. The FIPR offers workshops for teachers that are designed to enhance the knowledge teachers have of phosphate and its natural processes. Teachers in the workshop will be able to understand concepts through fieldtrips with experts in the field, as well as learn basic facts relevant to Florida and their classroom applications. Teachers will collaborate with one another to develop curriculum resources related the SSS.

\section{Public Service Commission (PSC)}

The Florida Public Service Commission is responsible for setting utility rates and ensuring efficient, safe, and reliable utility services in Florida. The utilities they oversee are electric, gas, telephone, water, and water resources. The PSC provides numerous consumer brochures and fact sheets that address topics such as energy and water conservation (Table 2). The PSC offers resources and up-to-date news about the utilities in Florida, their rates, and the meetings regarding their implementation. The PSC website has a link to access all meetings and agendas with audio and video files in order to observe what type of management is being undergone in regards to utilities. These meetings are free to watch and are available any time.

The PSC is organized into a system of oversight and management that is dictated by the five Public Service Commissioners. This organization system is able to be viewed on the PSC website in its entirety. The system's goal is to maintain economical and safe utilities to citizens in the most reliable way possible. 
Table 1. Summary contact information for federal agencies.

\begin{tabular}{|c|c|c|}
\hline Federal Agency & Main Website & \begin{tabular}{c} 
Environmental Education Website \\
\hline Forest Service
\end{tabular} \\
\hline $\begin{array}{c}\text { Natural Resources Conservation } \\
\text { Service }\end{array}$ & http://www.nrcs.usda.gov & $\begin{array}{c}\text { http://www.nrcs.usda.gov/wps/portal/nrcs/main/national/people/ } \\
\text { outreach/education }\end{array}$ \\
\hline National Park Service & http://www.nps.gov & http://www.nps.gov/learn \\
\hline Fish and Wildlife Service & http://www.fws.gov & http://www.fws.gov/letsgooutside/ \\
\hline $\begin{array}{c}\text { Environmental Protection } \\
\text { Agency }\end{array}$ & http://www.epa.gov & http://www.epa.gov/students/ \\
\hline $\begin{array}{c}\text { United States Geological Survey } \\
\text { National Oceanic and }\end{array}$ & http://www.usgs.gov & http://education.usgs.gov/ \\
\hline Atmospheric Administration & http://www.noaa.gov & http://www.education.noaa.gov \\
\hline
\end{tabular}

Table 2. Contact details for state agencies

\begin{tabular}{|c|c|}
\hline Florida State Agency & Main Website \\
\hline Dept. of Environmental Protection & http://www.dep.state.fl.us/ \\
\hline Office of Greenways and Trails & http://www.dep.state.fl.us/secretary/ed \\
\hline Division of Recreation and Parks & http://www.dep.state.fl.us/gwt \\
\hline Division of Recreation and Parks & http://www.dep.state.fl.us/parks \\
\hline Dept. of Agriculture \& Consumer Services & http://doacs.state.fl.us/ \\
\hline Florida Forest Service & http://www.floridaforestservice.com/ \\
\hline Project Learning Tree & http://sfrc.ufl.edu/plt \\
\hline \multirow[t]{3}{*}{ Fish \& Wildlife Conservation Commission } & http://www.myfwc.com \\
\hline & http://myfwc.com/about/inside-fwc/cr/ \\
\hline & http://myfwc.com/education/educators/project-wild/ \\
\hline Water Management Districts & http://www.dep.state.fl.us/secretary/watman \\
\hline \multirow[t]{3}{*}{ Project WET } & http://projectwet.org/ \\
\hline & http://www.dep.state.fl.us/secretary/ed/profdev/wet.htm \\
\hline & http://www.swfwmd.state.fl.us/education/projectwet/ \\
\hline Great Water Odyssey & http://www.sjrwmd.com/education/ \\
\hline Dept. of Transportation & http://www.dot.state.fl.us \\
\hline Environmental Management Office & http://www.dot.state.fl.us/emo \\
\hline Adopt-A-Highway & http://www.dot.state.fl.us/statemaintenanceoffice/aah.shtm/moreDOT/adopt.htm \\
\hline \multirow[t]{2}{*}{ Institute for Phosphate Research } & http://www.fipr.state.fl.us \\
\hline & http://www.fipr.state.fl.us/information-area-education.htm \\
\hline Public Service Commission & http://www.psc.state.fl.us \\
\hline Dept. of Education & http://www.fldoe.org/ \\
\hline
\end{tabular}

